\title{
MONOOXYGENASE SYSTEM IN GUERIN'S CARCINOMA OF RATS UNDER CONDITIONS OF $\omega$-3 POLYUNSATURATED FATTY ACIDS ADMINISTRATION
}

\author{
M. M. MARCHENKO, O. V. KETSA, I. O. SHMARAKOV, K. H. ABUTNARITSA \\ Fedkovich Chernovtsy National University, Ukraine; \\ e-mail: ketsa80@mail.ru
}

The aim of the study was to determine the variations of function in components of monooxygenase system (MOS) of rat Guerin's carcinoma under $\omega-3$ polyunsaturated fatty acids (PUFAs) administration. The activity of Guerin's carcinoma microsomal NADH-cytochrome $b_{5}$ reductase, the content and the rate of cytochrome $b_{5}$ oxidation-reduction, the content and the rate of cytochrome P450 oxidation-reduction have been investigated in rats with tumor under conditions of $\omega-3$ PUFAs administration. $\omega-3$ PUFAs supplementation before and after transplantation of Guerin's carcinoma resulted in the increase of NADH-cytochrome $b_{5}$ reductase activity and decrease of cytochrome $b_{5}$ level in the Guerin's carcinoma microsomal fraction in the logarithmic phases of carcinogenesis as compared to the tumor-bearing rats. Increased activity of $N A D H$-cytochrome $b_{5}$ reductase facilitates higher electron flow in redox-chain of MOS. Under decreased cytochrome $b_{5}$ levels the electrons are transferred to oxygen, which leads to heightened generation of superoxide $\left(\mathrm{O}_{2}^{-}\right)$in comparison to control. It was shown, that the decrease of cytochrome P450 level in the Guerin's carcinoma microsomal fraction in the logarithmic phases of oncogenesis under $\omega-3$ PUFAs administration may be associated with its transition into an inactive form - cytochrome P420. This decrease in cytochrome P450 coincides with increased generation of superoxide by MOS oxygenase chain.

Key words: NADH-cytochrome $b_{5}$ reductase, cytochrome $b_{5}$, cytochrome P450, superoxide, microsomal fraction, Guerin's carcinoma, $\omega-3$ polyunsaturated fatty acids.

$\mathrm{P}$ olyunsaturated fatty acids (PUFAs) are the essential fatty acids that are not synthesized de novo by mammals and must be consumed with ration. Excessive $\omega-6$ PUFAs and high $\omega-6$ to $\omega-3$ ration in modern diet are important factors in pathogenesis of various diseases, including cancer [1]. $\omega-3$ PUFAs have been described to have a protective effect against cancer progression, though its molecular mechanisms remain unexplained $[2,3]$.

Consumed $\omega-3$ PUFAs are integrated into cellular membranes and then metabolized in by cyclooxygenases, lipoxygenases and cytochrome P450 (CYP) [4]. $\omega-3$ PUFAs conversion to oxygenated products by CYP-catalyzed metabolic pathway is one of the proposed mechanisms of their antitumor effects [5], as these products may directly or indirectly affect growth and proliferation of cancer cells $[6,7]$. Moreover, as components of membranes, $\omega-3$ PUFAs help maintain functional state of components of monooxygenase system (MOS) in endoplasmic reticulum, which affects anticancer drug metabolism.
Thus, the aim of the study was to determine the variations in functioning of MOS components in microsomal fraction of Guerin's carcinoma under (-3 PUFAs administration.

\section{Materials and Methods}

The experiments were performed on white female rats of $90-110 \mathrm{~g}$ body mass. The animal experiments were conducted in accordance with Recommendations in Methodology by Bioethics Expert Committee for Pre-Clinical and Other Studies Performed on Laboratory Animals (Kyiv, 2006). The animals were kept under standard conditions and fed granulated K-120-2 ration (Rezon-1, Ukraine). Guerin's carcinoma was used as a cancer model. $0.5 \mathrm{ml}$ of $30 \%$ carcinoma cell suspension in normal saline was implanted subcutaneously into thigh of a hind leg [8]. The animals were assigned to the following groups: I - animals inoculated with Guerin's carcinoma (experimental control); II - animals that were administered $\omega-3$ PUFAs prior- and post-Gue- 
rin's carcinoma injection; III - animals that were administered $\omega-3$ PUFAs prior to Guerin's carcinoma injection; IV - animals that were administered $\omega-3$ PUFAs post-Guerin's carcinoma injection.

w-3 PUFAs were administered as Vitrum Cardio Omega-3 (Unipharm Inc., USA), derived from fish oil. The content of the pharmaceutical was analyzed by HRGC 5300 gas chromatographer (Italy) in glass column $(3.5 \mathrm{~m})$ with Chromosorb W/HP sorbent in $10 \%$ Silar $5 \mathrm{CP}$ liquid phase at $140-250{ }^{\circ} \mathrm{C}$ $\left(2{ }^{\circ} \mathrm{C}\right.$ per min heating). The fatty acids were identified by standard Sigma chemicals. The pharmaceutical was determined to contain $32 \%$ eicosapentaenoic acid and $24 \%$ docosahexaenoic acid.

The animals of the corresponding groups were administered $\omega-3$ PUFAs for 4 weeks prior to the carcinoma implantation and then for the entire duration of tumor growth. Daily dose was $120 \mathrm{mg}$ of $\omega-3$ PUFAs per $1 \mathrm{~kg}$ of body mass.

The animals were decapitated under diethyl ether sedation at various stages of carcinoma development: 7-day (latent carcinogenesis), 14-day (logarithmic carcinoma growth), and 21-day (stable size). Microsomal fraction was obtained by differential centrifugation [9] and used to assay catalytic activity of NADH-cytochrome $b_{5}$ reductase (EC 1.6.2.2), cytochrome $b_{5}$ content and reduction rate [10], and cytochrome P450 content and rate of inactivation (EC 1.14.14.1) [11]. The rate of cytochrome $b_{5}$ reduction was measured at $\lambda=424 \mathrm{~nm}$ and $475 \mathrm{~nm}$ at $30 \mathrm{sec}$ intervals and expressed as $\Delta \mathrm{A}_{424-475}$ per mg of protein. The rate of cytochrome P450 inactivation was measured at $\lambda=420 \mathrm{~nm}$ and $450 \mathrm{~nm}$ at $3 \mathrm{~min}$ intervals and expressed as $\Delta \mathrm{A}_{420-450}$ per nmol of cytochrome P450.

The reactions of reductase and oxygenase electron-transport chains were initiated by NADH and $\mathrm{NADPH}$, correspondingly. Production of $\mathrm{O}_{2}^{\cdot-}$ was assayed in nitro blue tetrazolium (NBT) test [12], in which NBT is reduced to hydrazine tetrazolium (with maximum absorbance at $\lambda=540 \mathrm{~nm}$ ) in the presence of $\mathrm{O}_{2}^{-}$. Rate of $\mathrm{O}_{2}^{--}$production was expressed as nmol hydrazine tetrazolium per min per $\mathrm{mg}$ of protein (nmol $\cdot \mathrm{min}^{-1} \cdot \mathrm{mg}^{-1}$ of protein), assuming that extinction of 0.325 corresponds to $325 \mathrm{nmol}$ of superoxide radical [12].

Protein content was measured by Lowry assay [13]. The data were processed by analysis of variance method using Student's $t$-test.

\section{Results and Discussion}

The hydroxylation of $\omega-3$ PUFAs by isoforms of P450 depends largely on the reductive chain of MOS. Cytochrome- $b_{5}$ reductase, the first component of the chain, passes electrons to cytochrome $b_{5}$, which in turn passes them to CYP on the fifth stage of the monooxygenase cycle. Changes in functioning of reductive chain of MOS may result in variation of produced metabolites and direction of CYP-catalyzed reactions [14].

We determined the highest level of NADHcytochrome $b_{5}$ reductase activity during logarithmic growth phase of Guerin's carcinoma, with consecutive decrease (Fig. 1). This corresponds to a decrease in cytochrome $b_{5}$ content in this period (Fig. 2) and increased rate of its oxidation and reduction (Fig. 3, $B$ ), which may compensate for the decrease in its quantity.

The intensive growth period of Guerin's carcinoma is thus associated with increased cytochromeb5 reductase activity and rate of cytochrome $b_{5}$ reduction, which increased electron transfer to CYP [15].

The highest NADH-cytochrome $b_{5}$ reductase activity levels and the lowest cytochrome $b_{5}$ were detected in animals that were administered $\omega-3$ PUFAs both prior to and post-Guerin's carcinoma implantation. The cytochrome $b_{5}$ reductase activity increased 1.5 times (Fig. 1), and cytochrome $b_{5}$ content decreased 2.8 times during intensive tumor growth phase in the animals of this group in comparison to experimental control.

Higher NADH-cytochrome b5 reductase activity facilitates increased electron flow in MOS reductive chain. Yet under conditions of decreased cytochrome $b_{5}$ content the electrons may be transferred to molecular oxygen, raising its content 1.6 times that of control levels (Fig. 4).

The parameters of activity of NADH-dependent reductive systems in animals administered $\omega-3$ PUFAs after Guerin's carcinoma implantation did not differ from those of control group animals (Fig. 1, 2, and 3).

Administration of $\omega-3$ PUFAs prior to carcinoma implantation leads to increased NADH-cytochrome $b_{5}$ reductase activity (Fig. 1), decreased cytochrome $b_{5}$ content (Fig 2) and rate of cytochrome $b_{5}$ oxidation (Fig. 3) in comparison to control. Yet the changes are less pronounced than those of the group 


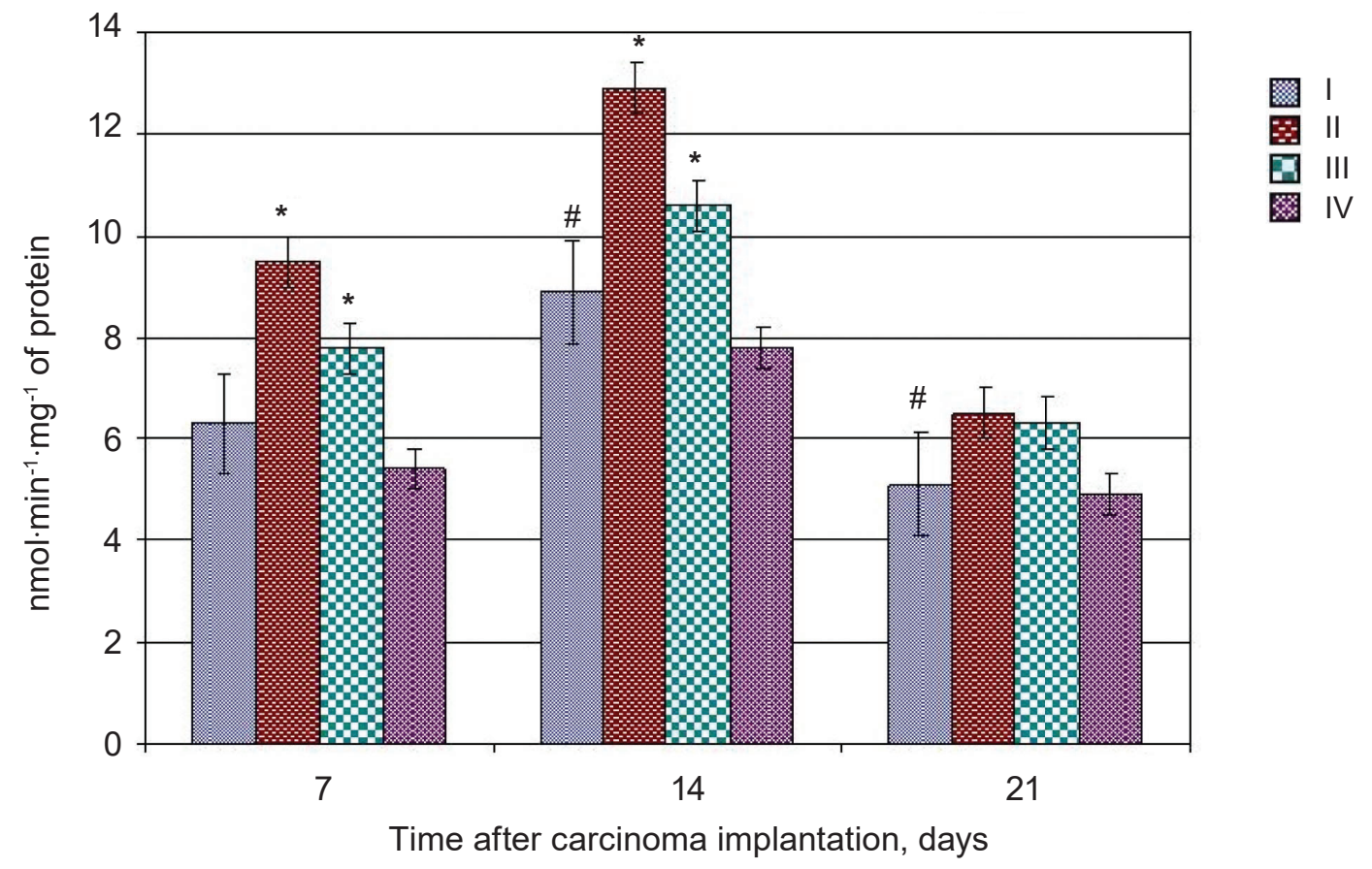

Fig. 1. Enzymatic activity of NADH-cytochrome $b_{5}$ reductase in microsomal fraction of Guerin's carcinoma under administration of $\omega-3$ PUFAs. Hereinafter: I - animals inoculated with Guerin's carcinoma (experimental control); II - animals that were administered $\omega-3$ PUFAs prior to and post-Guerin's carcinoma injection; III - animals that were administered $\omega-3$ PUFAs prior to Guerin's carcinoma injection; IV - animals that were administered $\omega-3$ PUFAs post-Guerin's carcinoma injection. * Denotes differences significant in comparison to group I ( $P \leq 0.05)$; \# denotes differences significant in comparison to the previous stage of carcinoma development in the same group $(P \leq 0.05)$

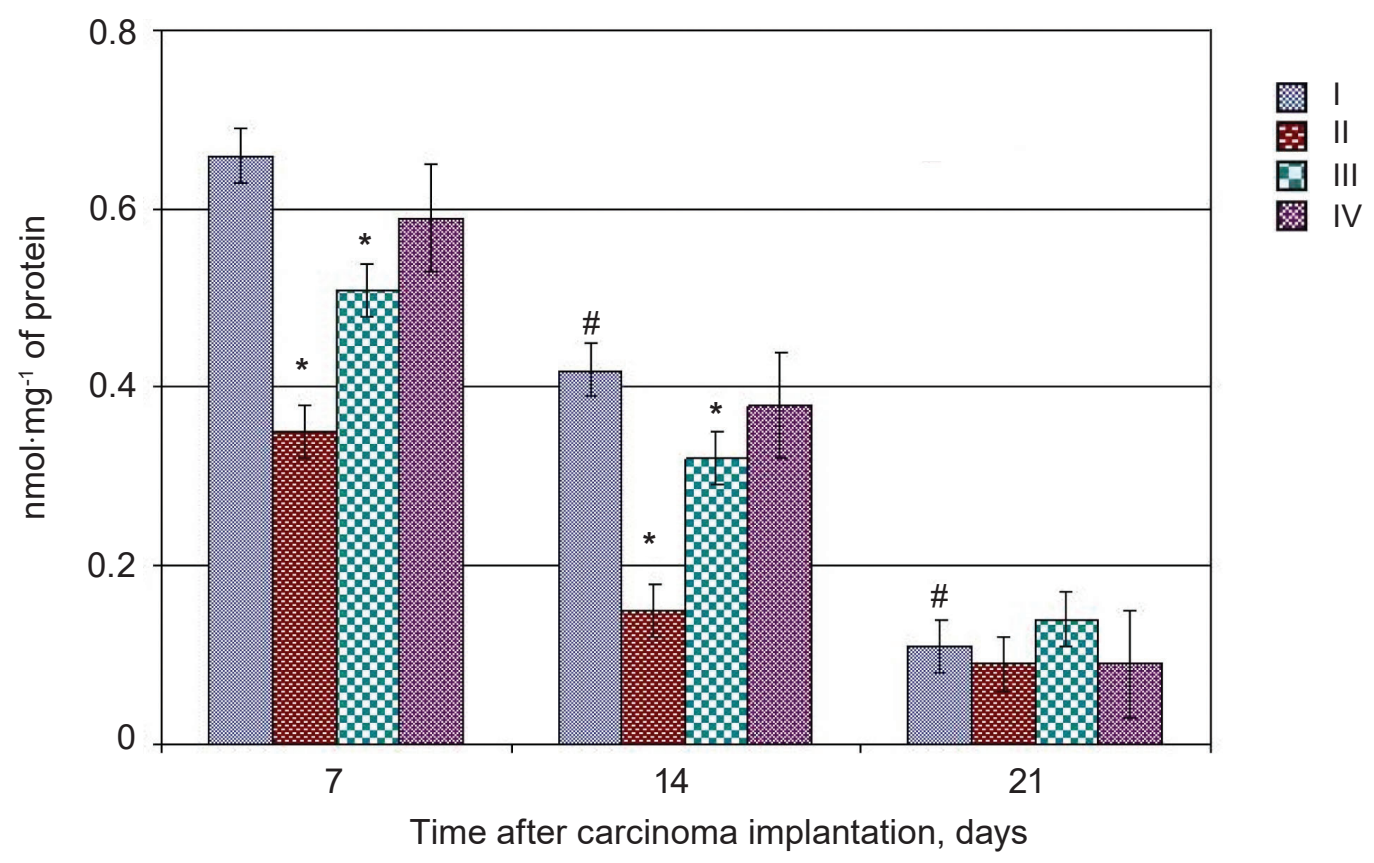

Fig. 2. Cytochrome $b_{5}$ content in microsomal fraction of Guerin's carcinoma under administration of $\omega-3$ PUFAs 

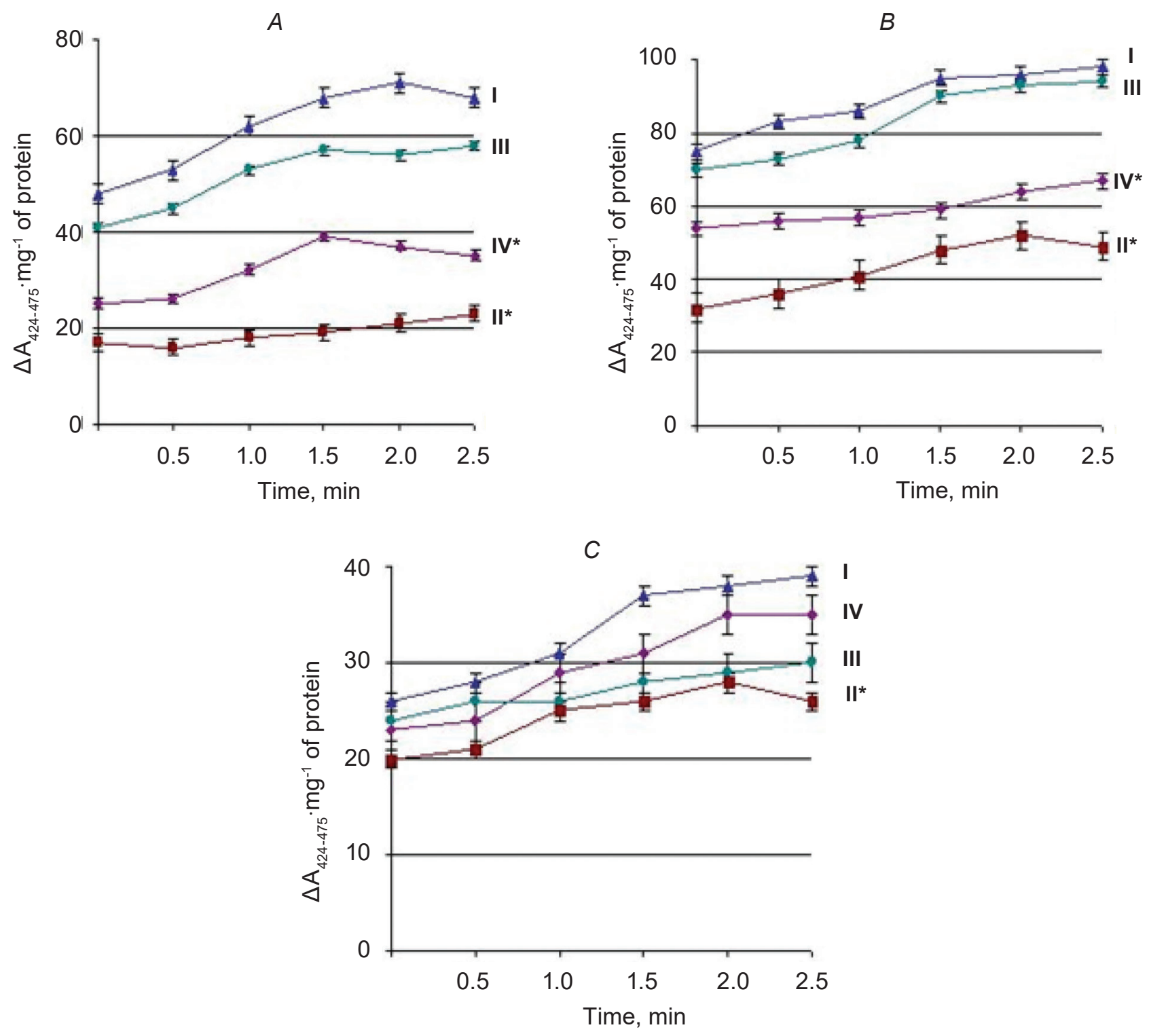

Fig. 3. The rate of cytochrome b5 reduction in microsomal fraction of Guerin's carcinoma under administration of $\omega-3$ PUFAs. A - 7 days after carcinoma implantation; $B$ - 14 days after carcinoma implantation; $C-21$ days after carcinoma implantation

receiving $\omega-3$ PUFAs both prior to and post-Guerin's carcinoma implantation.

Therefore, $\omega-3$ PUFAs administration prior to and post-implantation of Guerin's carcinoma leads to disruptions in functioning of components of MOS reductive chain.

As cytochrome $b_{5}$ is participating in reactions catalyzed by various CYP isoforms, its decreased content and reduction rate may adversely affect CYP functions.

We found decreased CYP content in microsomal fraction of Guerin's carcinoma in animals of the group that was administered $\omega-3$ PUFAs both before and post-implantation of the carcinoma in comparison to control during initial and logarithmic phases of carcinogenesis (Fig. 5). The decrease in CYP content may result from its inactivation and transformation in the inactive form, cytochrome P420 (Fig. 6). CYP is processed into cytochrome $\mathrm{P} 420$ by modifications of thiol groups in the active center. Inactive cytochrome $\mathrm{P} 420$ is unstable and rapidly loses heme in the presence of oxygen [16]. Cytochrome P420 production thus serves as a stage of CYP degradation in Guerin's carcinoma cells under $\omega-3$ PUFAs administration. 


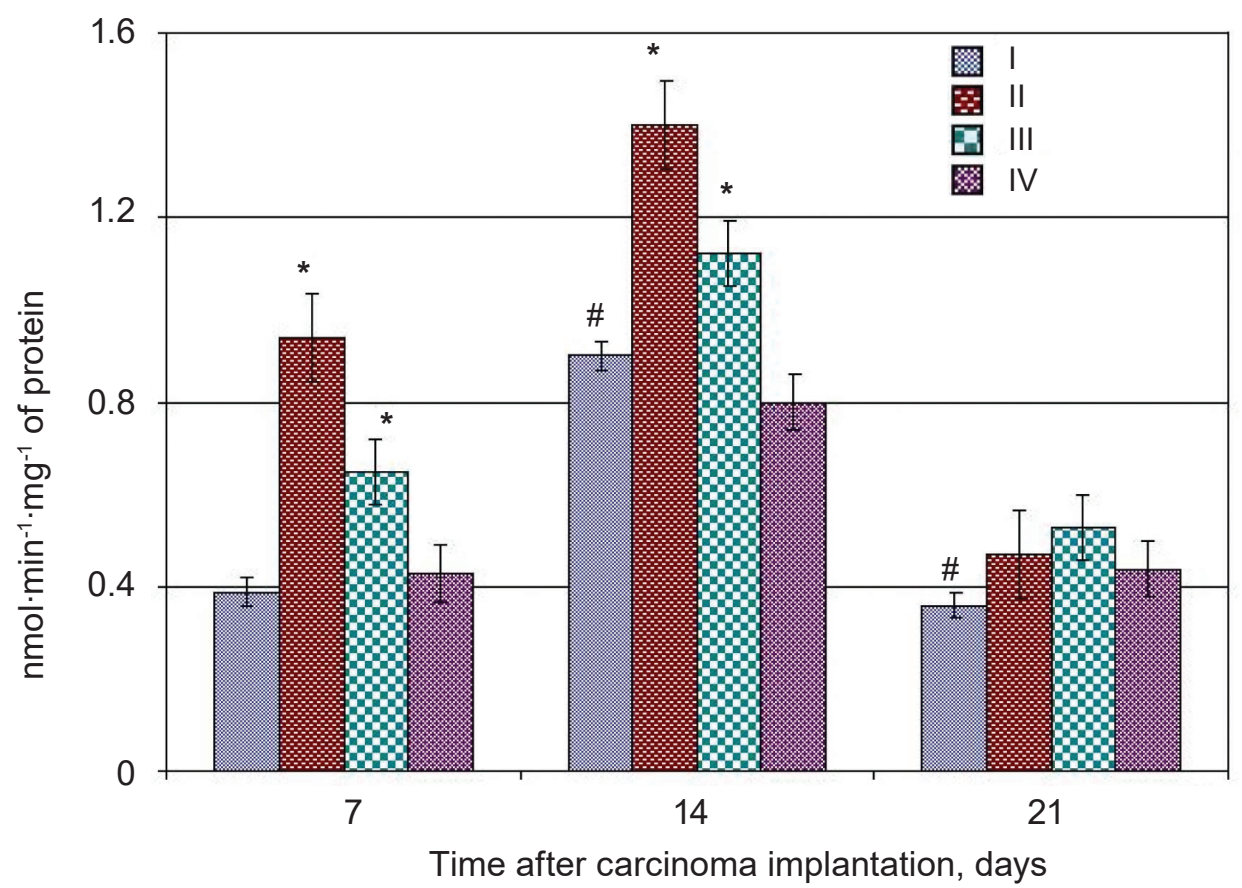

Fig. 4. The rate of superoxide generation by enzymes of reductive chain of MOS in microsomal fraction of Guerin's carcinoma under administration of $\omega-3$ PUFAs

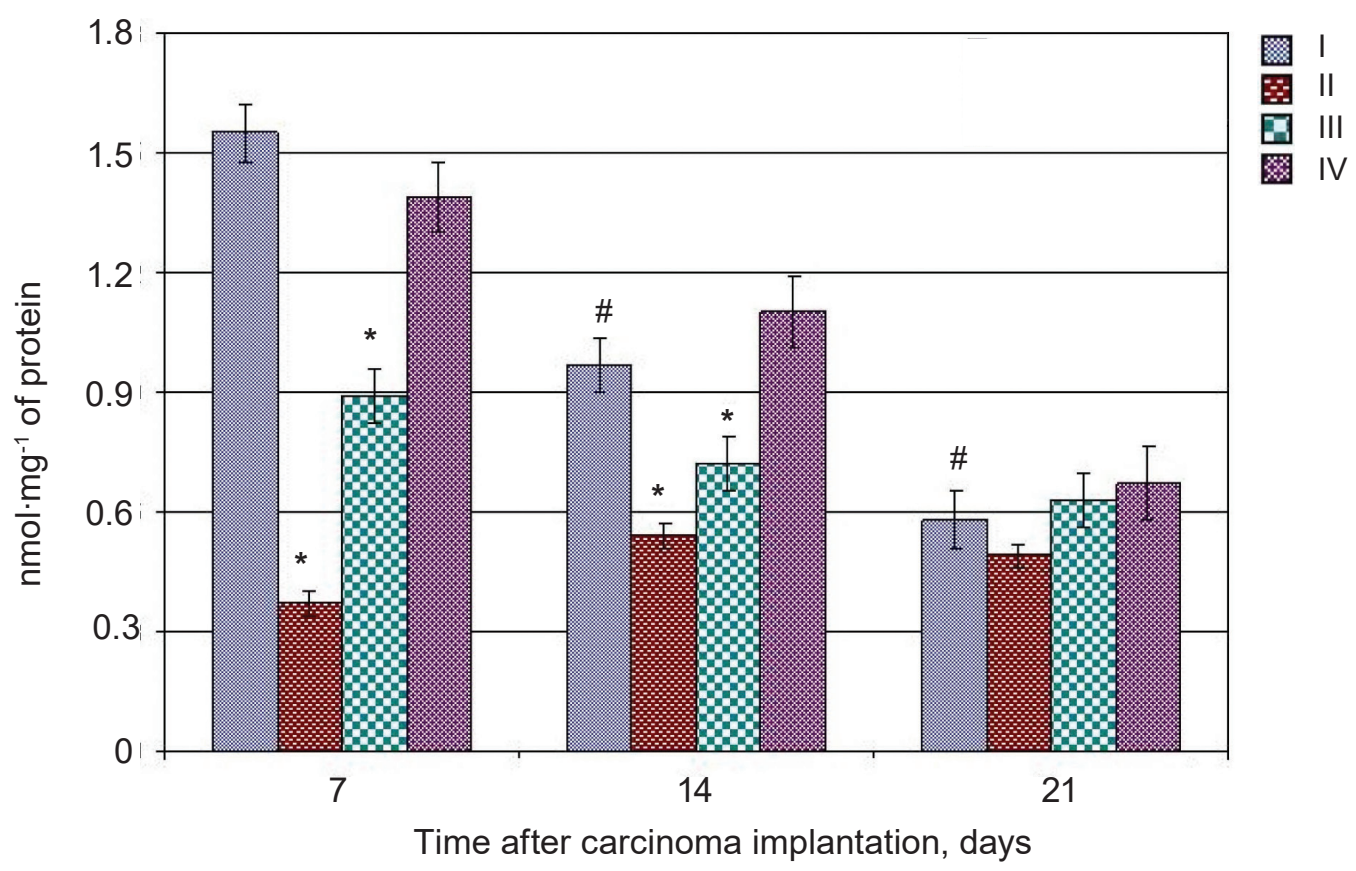

Fig. 5. CYP content in microsomal fraction of Guerin's carcinoma under administration of $\omega-3$ PUFAs

Decreased CYP content may lead to disruptions in monooxygenase cycle. Oxygen may not be fully incorporated into substrate, but partially released from triple substrate-CYP-oxygen complex - $(\mathrm{RH})$ $\mathrm{Fe}^{3+}\left(\mathrm{O}_{2}^{-}\right)$as superoxide radical [16]. We have established that a decrease in CYP content is associated with increased rate of superoxide generation by oxygenative chain of MOS under $\omega$-3 PUFAs administration prior to and post-Guerin's carcinoma implantation. $\mathrm{O}_{2}{ }^{--}$generation rate is 1.7 times higher during initial stage and 1.9 times higher during logarithmic growth in comparison to control values (Fig. 7). The 

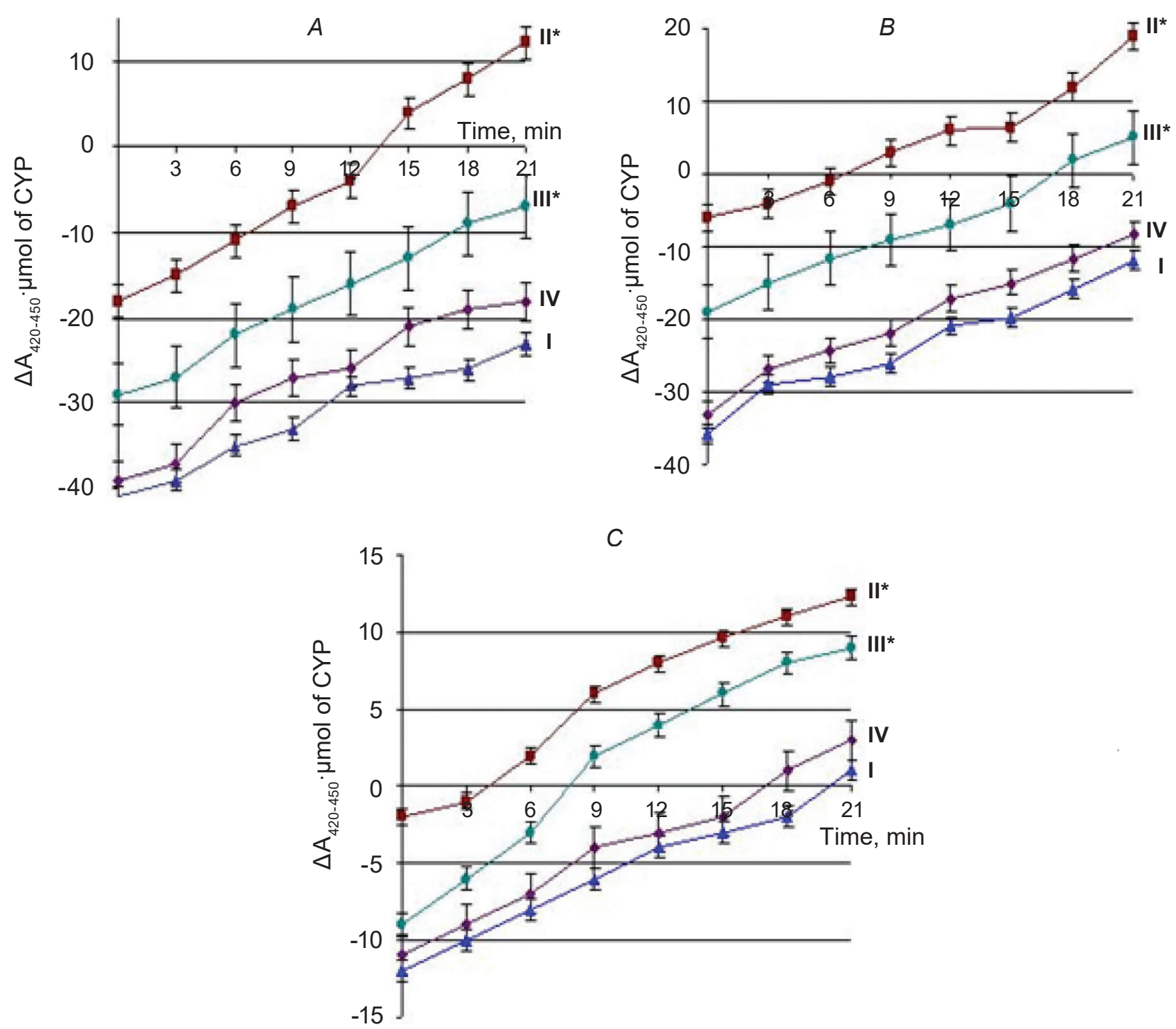

Fig. 6. The rate of CYP inactivation in microsomal fraction of Guerin's carcinoma under administration of $\omega-3$ PUFAs. $A-7$ days after carcinoma implantation; $B-14$ days after carcinoma implantation; $C-21$ days after carcinoma implantation

generated superoxide initiates oxidative modifications of proteins, including MOS constituents, and lipid peroxidation in endoplasmic reticulum membranes [17].

Therefore, $\omega-3$ PUFAs capacity to affect MOS action may be one of the mechanisms underlying their anticancer effect, due to a decrease in cytochrome $b_{5}$ and CYP content and increase in NADHcytochrome $b_{5}$ reductase activity, CYP inactivation rate, and superoxide generation in microsomal fraction of Guerin's carcinoma.

We propose the following mechanisms for the observed $\omega-3$ PUFAs influence of MOS:
1. $\omega-3$ PUFAs may initiate lipid peroxidation in endoplasmic reticulum membranes followed by degradation of membrane-bound proteins, including MOS enzyme complexes;

2. $\omega-3$ PUFAs increase generation rates of free radicals and reactive oxygen species by MOS enzymes;

3. $\omega-3$ PUFAs are catabolized by CYP into oxidized derivatives that may affect proliferation and apoptosis of tumor cells. 


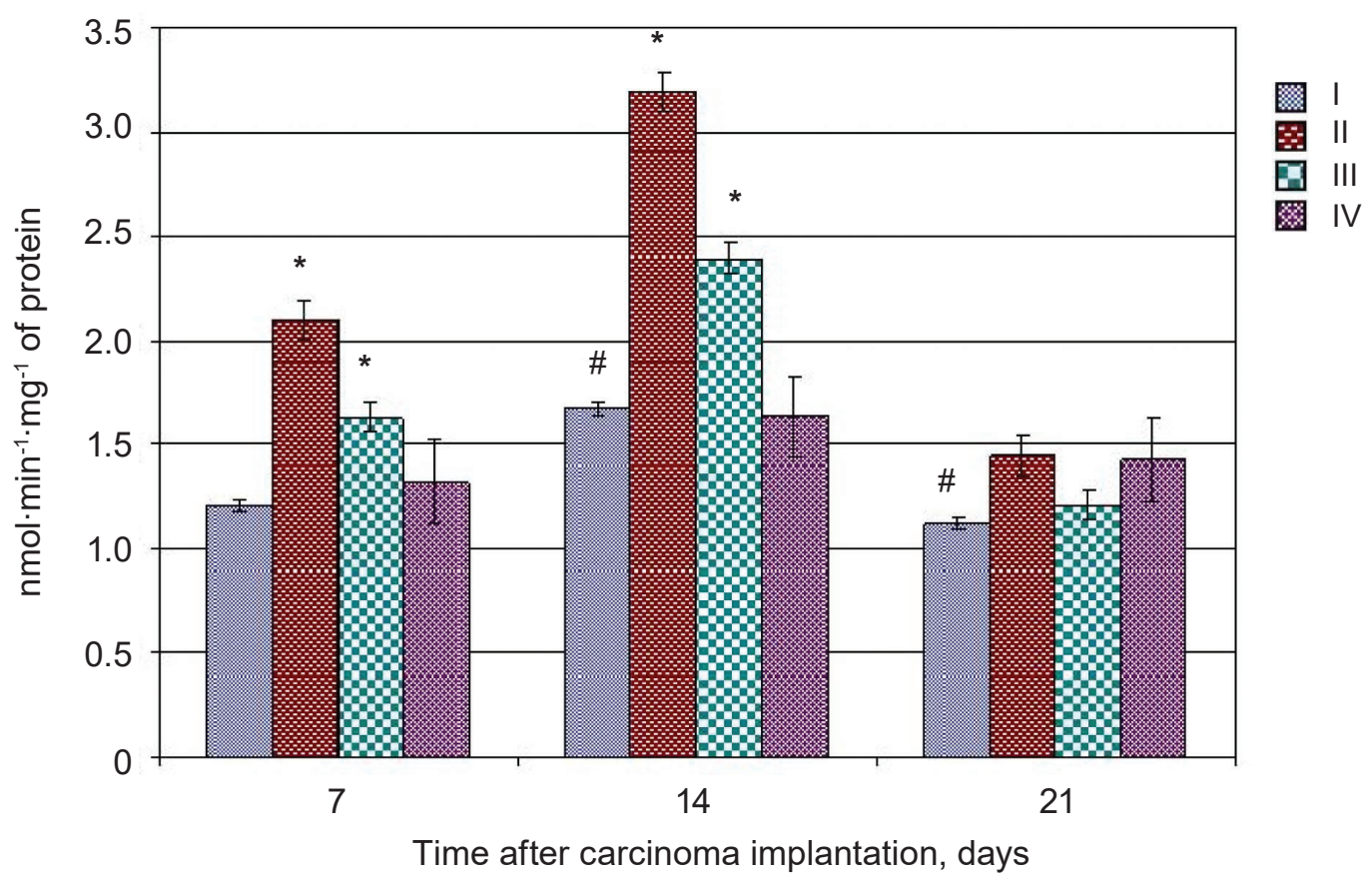

Fig. 7. The rate of superoxide generation by enzymes of oxygenative chain of MOS in microsomal fraction of Guerin's carcinoma under administration of $\omega-3$ PUFAs

\section{СТАН МОНООКСИГЕНАЗНОЇ СИСТЕМИ КАРЦИНОМИ ГЕРЕНА ЩУРІВ ЗА ВВЕДЕННЯ ПОЛІНЕНАСИЧЕНИХ ЖИРНИХ кИСЛОТ}

\section{М. М. Марченко, О. В. Кеича,}

I. О. Шмараков, К. Г. Абутнарійа
Чернівецький національний університет імені Юрія Федьковича, Україна; e-mail: ketsa80@mail.ru

У роботі проведено дослідження ензиматичної активності NADH-цитохром $b_{5}$ редуктази, вмісту і швидкості відновлення окислення цитохрому $b_{5}$, вмісту і швидкості інактивації цитохрому $\mathrm{P} 450$ у мікросомній фракції карциноми Герена щурів за введення

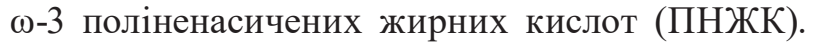
Показано, що введення $\omega$-ПНЖК до і після трансплантації тваринам карциноми Герена, приводило до підвищення ензиматичної активності NADH-цитохром $b_{5}$ редуктази та знижувало вміст цитохрому $b_{5}$ у мікросомній фракції пухлини в логарифмічну фазу онкогене- зу порівняно 3 контролем. Підвищення NADHцитохром $b_{5}$ редуктазної активності сприяло підвищенню потоку електронів у редуктазному редокс-ланцюзі монооксигеназної системи (MOC). За умов зниження вмісту цитохрому $b_{5}$ акцептором електронів може бути молекулярний кисень, внаслідок чого у 1,6 раза підвищувалась швидкість утворення супероксидного радикала $\left(\mathrm{O}_{2}{ }^{--}\right)$порівняно 3 контролем. Встановлено, що зниження вмісту цитохрому Р450 у мікросомній фракції карциноми Герена спостерігалося в логарифмічну фазу онкогенезу за введення $\omega-3$ ПНЖК. Зниження вмісту цитохрому Р450 супроводжувалося підвищенням швидкості його інактивації та переходу в неактивну форму - цитохром Р420. Показано, що зниження вмісту цитохрому Р450 відбувається на фоні підвищення генерації супероксидного радикала оксигеназним ланцюгом МOC.

Кл юч ов і слова: NADH-цитохром $b_{5}$ редуктаза, цитохром $b_{5}$, цитохром $\mathrm{P} 450$, супероксидний радикал, мікросомна фракція, карцинома Герена, $\omega-3$ поліненасичені жирні кислоти. 
СОСТОЯНИЕ

МОНООКСИГЕНАЗНОЙ

СИСТЕМЫ КАРЦИНОМЫ

ГЕРЕНА КРЫС ПРИ ВВЕДЕНИИ

Ф-3 ПОЛИНЕНАСЫЩЕННЫХ

ЖИРНЫХ КИСЛОТ

М. М. Марченко, О. В. Кеца,

И. А. Шмараков, К. Г. Абутнарииа

Черновицкий национальный университет имени Юрия Федьковича, Украина; e-mail: ketsa80@mail.ru

В работе проведено исследование энзиматической активности NADH-цитохром $b_{5}$ редуктазы, содержания и скорости восстановления окисления цитохрома $b_{5}$, содержания и скорости инактивации цитохрома P450 в микросомной фракции карциномы Герена крыс при введении $\omega-3$ полиненасыщенных жирных кислот (ПНЖК). Показано, что введение $\omega-3$ ПНЖК, до и после трансплантации животным карциномы Герена, приводит к повышению энзиматической активности NADH-цитохром $b_{5}$ редуктазы и снижению содержания цитохрома $b_{5}$ в микросомной фракции опухоли в логарифмическую фазу онкогенеза в сравнении с контролем. Установлено, что снижение содержания цитохрома P450 в микросомной фракции карциномы Герена происходило в логарифмическую фазу онкогенеза при введении $\omega-3$ ПНЖК. Снижение содержания цитохрома Р450 сопровождалось повышением скорости его перехода в неактивную форму - цитохром Р420. Показано, что снижение содержания цитохрома Р450 происходит на фоне повышения генерации супероксидного радикала оксигеназной цепи MOC.

К л ю че в ы е с л о в а: NADH-цитохром $b_{5}$ редуктаза, цитохром $b_{5}$, цитохром $\mathrm{P} 450$, супероксидный радикал, микросомная фракция, карцинома Герена, $\omega-3$ полиненасыщенные жирные кислоты.

\section{References}

1. Serini S, Fasano E, Celleno L, Cittadini A, Calviello G. Potential of long-chain n-3 polyunsaturated fatty acids in melanoma prevention. Nutr Rev. 2014; 72(4): 255-266.

2. Wang $\mathrm{S}, \mathrm{Wu} \mathrm{J}$, Suburu J, Gu Z, Cai J, Axanova LS, Cramer SD, Thomas MJ, Perry DL, Edwards IJ, Mucci LA, Sinnott JA,
Loda MF, Sui G, Berquin IM, Chen YQ. Effect of dietary polyunsaturated fatty acids on castration-resistant Pten-null prostate cancer. Carcinogenesis. 2012; 33(2): 404-412.

3. Berquin IM, Edwards IJ, Chen YQ. Multitargeted therapy of cancer by omega-3 fatty acids. Cancer Lett. 2008; 269(2): 363-377.

4. Davidson J, Rotondo D, Rizzo MT, Leaver HA. Therapeutic implications of disorders of cell death signalling: membranes, microenvironment, and eicosanoid and docosanoid metabolism. Br J Pharmacol. 2012; 166(4): 1193-1210.

5. Greene ER, Huang S, Serhan CN, Panigrahy D. Regulation of inflammation in cancer by eicosanoids. Prostaglandins Other Lipid Mediat. 2011; 96(1-4): 27-36.

6. Gladine C, Mazur A. Nutrigenomic effects of omega-3 fatty acids. Lipid Technology. 2014; 26(10): 227-229.

7. Recchiuti A, Serhan CN. Pro-Resolving Lipid Mediators (SPMs) and Their Actions in Regulating miRNA in Novel Resolution Circuits in Inflammation. Front Immunol. 2012; 3: 298.

8. Shmarakov IA, Katan NV. The Induction of Guerin's carcinoma cytochrome P450 hydroxylase activity by retinoids. Biochemistry (Mosc). Suppl Ser B Biomed Chem. 2011; 5(4): 369-375.

9. Schenkman JB, Cinti DL. Preparation of microsomes with calcium. Methods Enzymol. 1978; 52: 83-89.

10. Orekhovich VN. Ed., Moden method in biochemistry, Moscow: Meditsina. 386 p. (In Russian).

11. Mokhosoev IM, Kuznetsova GP, Al'terman MA, Bachmanova GI, Archakov AI. Inactivation of sodium dithionite reduced cytochromes P-450 of different origins. Biokhimiia. 1987; 52(10): 1649-1658. (In Russian).

12. Kostenko VO, Tsebrzhins'kii OI. Production of superoxide anion radical and nitric oxide in renal tissues sutured with different surgical suture material. Fiziol Zh. 2000; 46(5): 56-62. (In Ukrainian).

13. Lowry $\mathrm{OH}$, Rosenbrough $\mathrm{MJ}$, Farr $\mathrm{AL}$, Rendal RJ. Protein measurement with the Folin phenol reagent. J Biol Chem. 1951; 193(1): 265275.

14. Marchenko MM, Ketsa OV, Veliky NN. Biochemical transformation of xenobiotics in 
the body: monograph. Chernivtsi: Chernivtsi University, 2011. 280 p. (In Ukrainian).

15. Marchenko MM, Kopylchuk HP, Ketsa OV, Shmarakov IO. Effect of liposomal antitumor preparation 5-(5',6'-benzocoumarin-3')-methylaminouracil hydrobromide on cytochrome P-450 in the microsomal liver fraction of tumor bearing rats. Ukr Biokhim Zhurn. 2006; 78(6): 86-92. (In Ukrainian).
16. Kaur R, Arora S. Interactions of betulinic acid with xenobiotic metabolizing and antioxidative enzymes in DMBA-treated Sprague Dawley female rats. Free Radic Biol Med. 2013; 65: 131142.

17. Guengerich FP. Cytochrome p450 and chemical toxicology. Chem Res Toxicol. 2008; 21(1): 70-83.

Received 09.03.2016 